\title{
Winter Survival and Source of Primary Inoculum of Powdery Mildew of Dogwood in Tennessee
}

\author{
Margaret T. Mmbaga, Tennessee State University, Nursery Crop Research Station, 472 Cadillac Lane, \\ McMinnville 37110
}

\begin{abstract}
Mmbaga, M. T. 2000. Winter survival and source of primary inoculum of powdery mildew of dogwood in Tennessee. Plant Dis. 84:574-579.

A 3-year study (1996-1998) on the epidemiology of dogwood powdery mildew showed that Microsphaera pulchra is the primary powdery mildew pathogen of dogwoods (Cornus spp.) in mid-Tennessee, and the occurrence of Phyllactinia guttata is insignificant. Cleistothecia harvested from leaf debris in spring contained viable asci and ascospores and produced powdery mildew infection on disease-free plants. Ascospores that were morphologically similar to those of M. pulchra were trapped on sticky slides in the vicinity of dogwoods throughout spring. Previously infected plants that did not harbor cleistothecia failed to develop signs of infection under growth-chamber and greenhouse conditions conducive to powdery mildew infections. Results from these studies indicate that cleistothecia on leaf debris rather than mycelia on dormant buds constitute the main winter survival structure and primary sources of spring inoculum in mid-Tennessee.
\end{abstract}

Powdery mildew of dogwood (Cornus spp.) emerged as a nursery production problem only 4 to 5 years ago and is now regarded as one of the most important diseases constraining nursery production of Cornus florida in the southeastern United States $(4,5,8,12)$. Two fungi have been reported to cause powdery mildew in Cornus spp.: Phyllactinia guttata (syn. P. corylea; 8,14) and Microsphaera pulchra $(7,12)$. Studies in Tennessee on two Cornus spp. suggested that M. pulchra is the primary powdery mildew pathogen of $C$. florida, while $P$. guttata occurred more frequently in $C$. amomum (7). The perfect stage was seen to occur late in the growing season, while the imperfect stage, Oidium spp. for M. pulchra and Ovulariopsis spp. for $P$. guttata, dominated throughout the growing season $(9,10)$. These observations suggested that $M$. pulchra was the dominant pathogen on $C$. florida and $C$. kousa in Tennessee, while $P$. guttata was relatively insignificant $(9,10)$. However, cleistothecia of both $P$. guttata and M. pulchra were equally abundant on $C$. florida in Kentucky (6), indicating that both fungi were important pathogens of dogwood.

Previous reports indicate that the mild winters in the southeastern United States

Corresponding author: M. T. Mmbaga

E-mail: plantpath@blomand.net

Some of the work reported here was done under USDA/CSREES Grant No. 98-38814-6236.

Accepted for publication 7 February 2000.

Publication no. D-2000-0323-03R

(C) 2000 The American Phytopathological Society may not allow frequent occurrence of cleistothecia (14). In such situations, various powdery mildew fungi may overwinter as mycelium on dormant buds (15), chlamydospores, or as active infections (17). Since powdery mildew emerged as an important disease of dogwood, it has been commonly assumed that the pathogen overwinters in dormant plants. Preliminary studies on previously infected dogwood plants from various nurseries in mid-Tennessee failed to reveal mycelia in the dormant buds (unpublished data). The presence of cleistothecia suggested a potential mechanism for winter survival, but mere presence was not proof of a functional and important role in the disease cycle (2). For example, cleistothecia are formed by Sphaerotheca pannosa on roses and by $M$. syringae on lilac, but there is little experimental evidence to indicate that they retain function, and only circumstantial evidence indicates that these obligate pathogens can overwinter in dormant buds (17). Currently, dogwood producers in the southeastern United States routinely apply fungicides to control powdery mildew (16). Information on winter survival and source of primary inoculum will benefit the timing of fungicide applications and disease control strategies (3). The objectives of this study were to evaluate the role of infected dormant buds and cleistothecia in winter survival and to determine the source of primary inoculum for dogwood powdery mildew.

\section{MATERIALS AND METHODS}

Cleistothecium development and winter survival. Based on preliminary observations in mid-Tennessee that cleistothecia of dogwood powdery mildew develop late in the growing season, documentation of cleistothecia was initiated in September 1996. Leaf samples for detailed studies were collected from six nurseries and six landscape areas every 2 weeks. Samples collected between mid-November and midDecember were used for location comparisons; at this time, there was the highest number of mature cleistothecia and trees had not yet defoliated completely. Samples of 100 to 200 senescing leaves were collected from plants and from leaf litter on the ground from various species and cultivars grown in the test sites. Also included in the samples were 10 to 15 terminals, each approximately 6 to $10 \mathrm{~cm}$ in length, with vegetative and flower buds.

A hand lens (10x) was used to observe cleistothecia on the plant material in the field before sample collection. A dissecting microscope $(35 x)$ was used to assess the maturity, frequency, and abundance of cleistothecia, and a compound microscope (200 to 400x) was used to check for asci and ascospore development and viability. Cleistothecia were categorized as immature or mature and their abundance was assessed as cleistothecium density per leaf. Density was classified as high if the average number was $>50$ cleistothecia per leaf area (approximately $19.6 \mathrm{~mm}^{2}$ ), moderate at 25 to 49 cleistothecia per leaf area, and low at $<25$ cleistothecia per leaf area. Cleistothecia distribution was clustered or scattered; therefore, the abaxial and adaxial surfaces of the entire leaf were observed and the mean was used to categorize abundance.

Leaf samples with moderate to high densities of cleistothecia were cut into small pieces (approximately $1.5 \mathrm{~cm}^{2}$ ) and placed into plastic-mesh bags. The bags were then overwintered in four environments: (i) outdoors on the ground; (ii) outdoors hanging on a shrub (iii); outdoors on the ground, but protected from moisture and microbial activity by a ziplock bag; and (iv) indoors in a ziplock bag exposed to the prevailing temperatures, but protected from direct moisture or microbial activity.

Starting in February 1997 and March 1998, samples of about 20 leaf pieces were retrieved from each overwintering environment every 7 days and weighed. Leaf pieces were suspended in $200 \mathrm{ml}$ of water and placed on a platform shaker (Innova 2100, New Brunswick Scientific, Inc., 
Edison, NJ) at $150 \mathrm{rpm}$ for 2 to $3 \mathrm{~h}$. The leaves were periodically checked under a dissecting microscope until all cleistothecia had been released into the water. The suspension was passed through a large sieve to remove the leaf material and a vacuum filter was used to concentrate the cleistothecia (2). The cleistothecia were collected on Whatman no. 4 filter paper and counted. For microscopic observations of cleistothecia viability, 50 to 100 mature cleistothecia were removed from leaf pieces and crushed under a glass slide cover. Mature ascospores with vacuolated cytoplasm indicated viable ascospores, whereas degenerate ascospores with dark cytoplasm and numerous lipid droplets indicated nonviable ascospores (2).

The infectivity of the ascospores under growth chamber conditions of 28 and $20^{\circ} \mathrm{C}$ (day and night, respectively) and $85 \%$ relative humidity $(\mathrm{RH})$ was assessed using disease-free seedlings and mid-May 1998 leaf samples. Approximately 20 to 30 diseased leaf pieces wrapped with doublelayer cheesecloth were moistened with sterile distilled water and suspended over 1-year-old $C$. florida seedlings. Cleistothecia from each overwintering treatment were replicated on four plants within a complete randomized block design.

Spore dispersal. Spore traps were prepared using frosted microscope slides and Vaseline petroleum jelly following the method of Ostry and Nicholls (11). Spore traps were used to monitor the air around dogwood foliage for 7-day periods from February 1997 to June 1998. Three locations were used for spore traps: (i) evaluation plots, (ii) container yard, and (iii) for- est undergrowth where dogwood trees grew at the Nursery crop research station (McMinnville, $\mathrm{TN}$ ). The spore trap slides were held vertically by a clothes pin and a metal twist tie on each dogwood tree. Seven traps were placed at each location and were replaced every 7 days, the same time period used to study cleistothecia on leaf debris. Spores trapped on slides were observed under a compound microscope (400x) and compared with those harvested from leaf debris. Spores that resembled those of M. pulchra were counted.

Dormant buds as sources of inoculum. Seedlings (1 year old) of C. florida that were infected with powdery mildew were selected for this study. At the end of the 1996 and 1997 seasons, plants were carefully examined for cleistothecia to confirm that they did not have cleistothecia attached to the stem. The plants were then overwintered outdoors under a commercial spun-polyester winter fabric. Plants were retrieved from the winter location on 1 March and placed into one of the following environments: (i) outside exposed to airborne inoculum, (ii) in growth chambers sheltered from airborne spores, and (iii) in greenhouse conditions protected from airborne spores. At each location, plants were separated into two subgroups, one treated with fungicide, the other untreated. The systemic fungicide Banner (propioconazole) was used according to the label recommended rate of $2 \mathrm{fl} \mathrm{oz}(58.6 \mathrm{ml})$ per 100 gal (378.5 liters) of water, sprayed to runoff. Plants in growth chambers were maintained at 28 and $20^{\circ} \mathrm{C}$ (day and night, respectively) and $85 \% \mathrm{RH}$; plants in the greenhouses were maintained at 28 and $20^{\circ} \mathrm{C}$ (day and night) and $70 \% \mathrm{RH}$; and the outdoors temperatures ranged from 10 to $0^{\circ} \mathrm{C}$ and 31 to $23^{\circ} \mathrm{C}$ (day and night) for April to mid-June 1997. Development of disease symptoms was monitored daily. The experiment was terminated in midJune, when disease outbreaks were widespread in the local area.

\section{RESULTS}

Cleistothecium development and winter survival. In 1996, cleistothecial initials were first observed in early October, and cleistothecia developed in abundance at all locations observed in the landscape and nurseries. Both severely affected plants and plants without much visible mycelium had abundant cleistothecia on the abaxial and adaxial leaf surfaces. Observations from six nurseries revealed many cleistothecia on the two species examined (Table 1). Leaf samples from landscape areas also had large numbers of cleistothecia. $M$. pulchra was identified from all areas studied. A relatively small number of cleistothecia of $P$. guttata (six cleistothecia total) were found in two nurseries on $C$. florida and C. kousa. Plants in one nursery showed signs of mild disease on only a few leaves, but an abundance of cleistothecia were on these leaves. Cleistothecia were also found on some plants of C. kousa (resistant) and on C. florida cv. Cherokee Brave (moderately resistant) (Table 1). Cleistothecial initials were cream to light yellow in color, then turned brown to black and developed appendages. Mature cleistothecia were usually dark brown to black, with or without appendages, and contained asci with ascospores. Most of the cleis-

Table 1. Prevalence and abundance of cleistothecia on powdery mildew-infected dogwood plants

\begin{tabular}{|c|c|c|c|c|c|c|c|}
\hline \multirow[b]{2}{*}{ Year, nursery ${ }^{y}$} & \multirow[b]{2}{*}{ County (TN) } & \multirow[b]{2}{*}{ Species and cultivars ${ }^{\mathrm{Z}}$} & \multirow[b]{2}{*}{ No. leaves examined } & \multirow[b]{2}{*}{ Leaves with cleistothecia (\%) } & \multicolumn{3}{|c|}{ Cleistothecia abundance $^{x}$} \\
\hline & & & & & Low & Moderate & High \\
\hline \multicolumn{8}{|l|}{1996} \\
\hline 1 & Warren & Cornus florida* & 100 & 86 & 40 & 20 & 26 \\
\hline 2 & Warren & C. florida & 130 & 100 & 30 & 50 & 50 \\
\hline 3 & Warren & C. florida & 100 & 83 & 36 & 16 & 31 \\
\hline 4 & Franklin & C. florida & 50 & 60 & 21 & 7 & 2 \\
\hline 5 & Franklin & C. florida & 50 & 100 & 16 & 13 & 21 \\
\hline 5 & Franklin & Brave & 40 & 30 & 8 & 2 & 2 \\
\hline 6 & Franklin & C. florida & 100 & 92 & 40 & 22 & 30 \\
\hline 6 & Franklin & C. kousa* & 20 & 50 & 7 & 2 & 1 \\
\hline \multicolumn{8}{|l|}{1998} \\
\hline 1 & Warren & C. florida & 120 & 0 & 0 & 0 & 0 \\
\hline 2 & Warren & C. florida & 50 & 0 & 0 & 0 & 0 \\
\hline 3 & Franklin & Brave & 50 & 0 & 0 & 0 & 0 \\
\hline 3 & Franklin & Rubra & 90 & 3.3 & 3 & 0 & 0 \\
\hline 3 & Franklin & Princess & 200 & 4.5 & 8 & 1 & 0 \\
\hline 3 & Franklin & C. florida & 100 & 0 & 0 & 0 & 0 \\
\hline 3 & Franklin & C. kousa & 100 & 1.0 & 1 & 0 & 0 \\
\hline 4 & Franklin & C. kousa & 170 & 1.8 & 0 & 3 & 0 \\
\hline 4 & Franklin & C. florida & 300 & 0 & 0 & 0 & 0 \\
\hline 5 & Dekalb & Rubra & 160 & 3.1 & 0 & 5 & 0 \\
\hline 5 & Dekalb & C. florida & 150 & 8.7 & 0 & 12 & 1 \\
\hline 5 & Dekalb & C. florida & 80 & 11.3 & 3 & 6 & 0 \\
\hline
\end{tabular}

${ }^{x}$ Number of leaves with different cleistothecium densities per $19.6 \mathrm{~mm}^{2}$ leaf area as observed under a dissecting microscope $(35 \times)$ : high abundance $=>50$, moderate abundance $=25$ to 49 , and low abundance $=<25$ cleistothecia

y 1997 data (not shown) was similar to that of 1998.

$\mathrm{z} *=$ Phyllactinia guttata was observed; Brave, Rubra, and Princess $=$ C. florida cultivars Cherokee Brave, Rubra, and Cherokee Princess, respectively. 
tothecia matured before the end of the growing season and had produced ascospores. Both young and old leaves had cleistothecia on abaxial and adaxial surfaces. Within a plant, the more severely affected leaves did not necessarily have more cleistothecia than the less affected leaves.

In 1997 and 1998, the cleistothecia developed in early November, about a month later than in 1996 (data not shown). Cleistothecia abundance in 1997 was only about $25 \%$ of that observed in 1996, and was even lower in 1998. In 1997 and 1998, the more severely affected plants had more cleistothecia than the mildly affected plants and cleistothecia were apparent at some locations and absent at others. All cleistothecia observed were of $M$. pulchra; $P$. guttata was not observed. The maximum temperatures for the September and October months preceding cleistothecium formation were cooler in 1996 than in 1997 and 1998, but the minimum temperatures were similar (data not shown). Of the 17 samples collected in mid-November 1998 from areas where fungicides had not been used, $9(53 \%)$ did not have any cleistothecia, $3(18 \%)$ had a low density of cleistothecia, and $5(29 \%)$ had a moderate density of cleistothecia. Leaves collected from nurseries where fungicides were routinely used had a very low occurrence of cleistothecia. Overall, the abundance of cleistothecia in 1998 was very low compared to 1996 (Table 1). The development of cleistothecium initials coincided with the maximum temperature dropping below $80^{\circ} \mathrm{C}$ for several days (September 1996 and October 1997 and 1998). A few days of freezing temperature occurred in early November 1998 when cleistothecia were still delicate (cream-yellow initial); this may have affected the abundance of ascocarps shown in Table 1 . No cleistothecia were observed on the stems, even on the severely affected plants. Overall disease severity was high in 1996 and 1997 but, in 1998, disease severity was moderate in nurseries and landscapes (data not shown).

Cleistothecia harvested from overwintered leaf debris placed at outdoor locations showed similar trends of development and numbers (Fig. 1). Numbers of immature cleistothecia decreased steadily over time, while numbers of mature cleistothecia that had not opened remained steady through early May and then started to decline. Cleistothecia that had opened and were empty, suggesting that they had liberated their ascospores, increased in number over time, with the highest numbers occurring in May and early June (Fig. 2). The first disease symptoms were observed in early May.

Evaluation of cleistothecia viability in mid-May 1997 and 1998 showed that 17 to
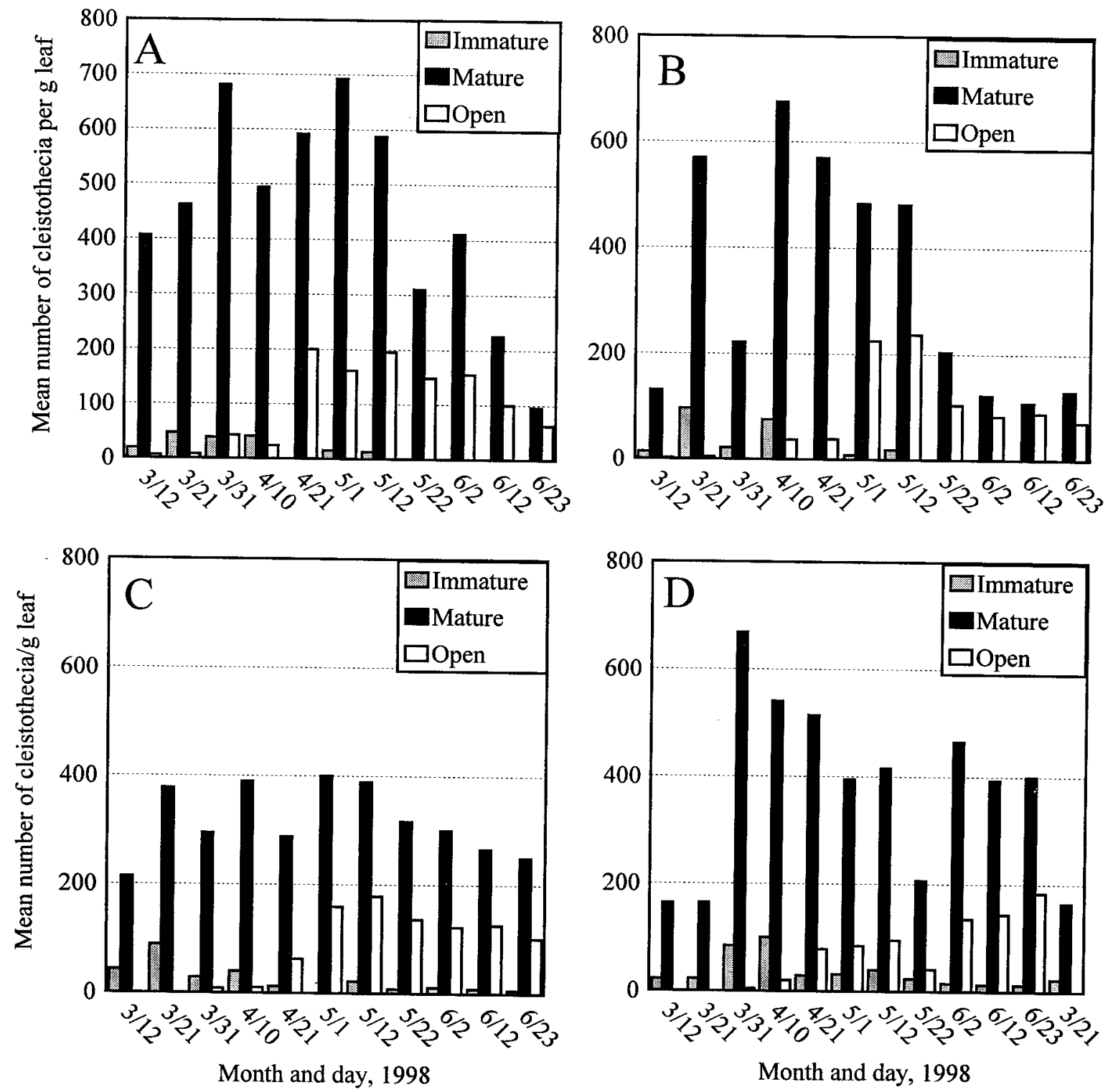

Fig. 1. Powdery mildew ascocarps (cleistothecia) harvested from dogwood leaf debris overwintered in four environments: (A) outdoors on the ground, (B) outdoors hanging on a shrub, (C) outdoors on the ground but protected from moisture and microbial activity by a ziplock bag, and (D) indoors in an unheated area. Data shown are from 1998, but similar results were obtained in 1997. 
$25 \%$ of the cleistothecia in outdoor locations were open and empty, 37 to $44 \%$ carried asci and viable ascospores, and 36 to $40 \%$ had degenerate asci. About $63 \%$ of the cleistothecia from the indoor winter location were open and empty, $11 \%$ were viable, and the remaining $26 \%$ were degenerate (Table 2). The leaves maintained indoors in ziplock bags were exposed to moisture formed inside the bags for about 1 month; this could have triggered all mature cleistothecia to release their contents. Ascocarps of $M$. pulchra that had overwintered on leaf debris reproduced powdery mildew infection on $50 \%$ of the disease-free plants exposed to inoculum (Table 2). This was confirmation of the functional status of cleistothecia overwintered on leaf debris. No infection resulted from leaf debris overwintered indoors in a nonheated area; however, this was not surprising because most of the cleistothecia that had not released their spores had degenerate asci.

Spore dispersal. Spores that resembled ascospores of $M$. pulchra were trapped on the spore traps as single spores or as groups of eight or four. In addition, mature ascospore-containing asci that resembled those of M. pulchra were also trapped from the air between March and June 1997 and 1998 (Fig. 3). Conidiospores were observed on the spore traps before disease symptoms were visible in the local area;

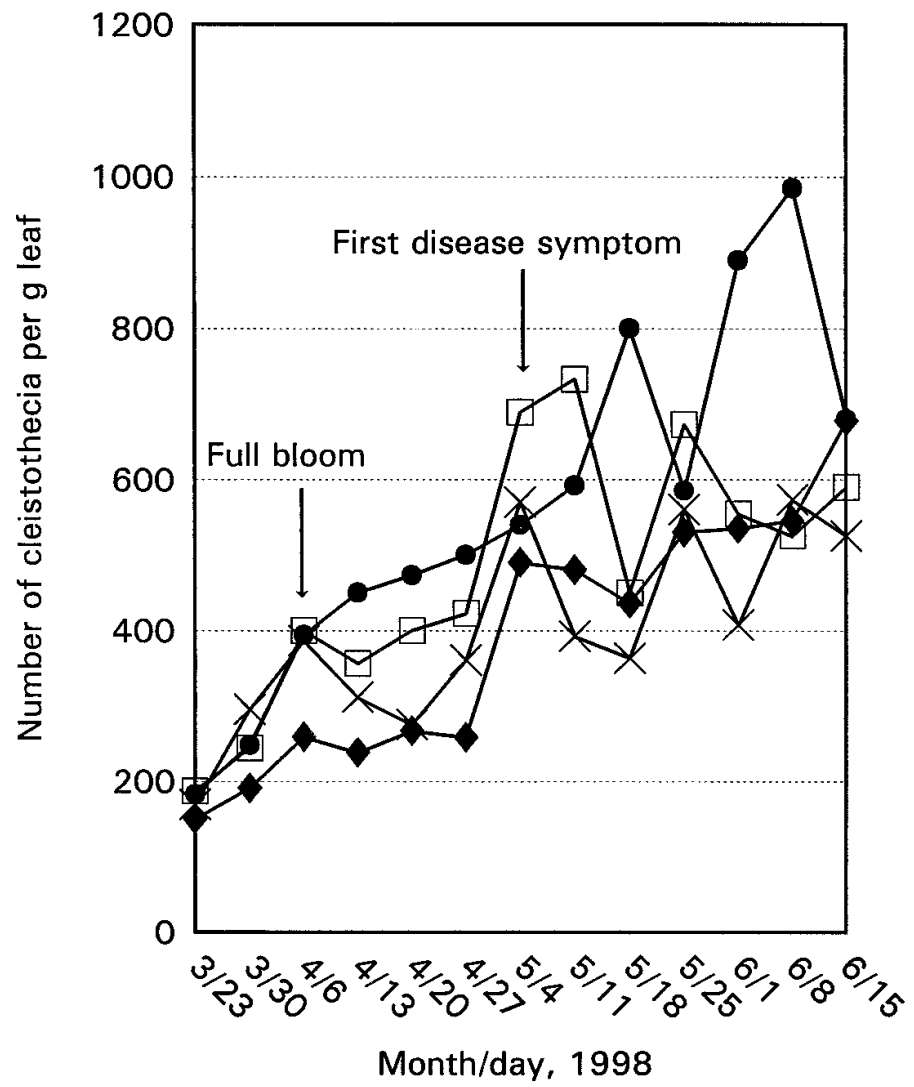

Fig. 2. Number of cleistothecia per gram of leaf that had opened and released ascospores in spring 1998 after overwintering on leaf debris in four environments: $(\bullet)$ outdoors on the ground, $(\square)$ outdoors hanging on a shrub, $(\diamond)$ outdoors on the ground but protected from moisture and microbial activity by a ziplock bag, and $(x)$ indoors in a nonheated area. Similar results were obtained in 1997.

Table 2. Winter survival of cleistothecia as measured by visual assessment of viability and infectivity of ascospores in 1998

\begin{tabular}{lcccc}
\hline & \multicolumn{2}{c}{ Total cleistothecia with asci and ascospores $(\text { mean \% })^{\mathbf{x}}$} & \\
\cline { 2 - 4 } Overwintering location & Open and empty & Viable & Nonviable & Plants infected $^{\mathbf{y}}$ \\
\hline Outdoors on the ground & $25.3 \mathrm{~b}$ & $38.6 \mathrm{ab}$ & $36.1 \mathrm{a}$ & $2 / 4$ \\
Outdoors protected & $16.7 \mathrm{~b}$ & $43.5 \mathrm{a}$ & $39.8 \mathrm{a}$ & $2 / 4$ \\
Outdoors hanging & $24.9 \mathrm{~b}$ & $36.6 \mathrm{~b}$ & $38.4 \mathrm{a}$ & $1 / 4$ \\
Indoors unheated & $62.7 \mathrm{a}$ & $11.2 \mathrm{c}$ & $26.1 \mathrm{~b}$ & $0 / 4$ \\
\hline
\end{tabular}

${ }^{x}$ Open and empty cleistothecia had no asci or ascospores, viable ascospores had vacuolated cytoplasm and no oil droplets, and nonviable asci or ascospores were degenerate with dark cytoplasm and numerous oil droplets. Numbers followed by the same letters within a column are statistically similar according to a least significant difference test $(P<0.05)$.

${ }^{y}$ Number of plants that became infected from leaf debris over total number exposed to inoculum.

${ }^{\mathrm{z}}$ Leaf debris was protected with a clear plastic ziplock bag. more conidiospores than ascospores were observed at study termination. In the two seasons, ascospore and ascus abundance on spore traps seemed related to rainfall trends (Fig. 3). The mean number of airborne ascospores and asci trapped was highest in the landscape plots, whereas the mean number of conidiospores was highest in the forest undergrowth location (Fig. 4).

Dormant buds as sources of inoculum. None of the 16 plants maintained under growth-chamber conditions or the 40 plants held under greenhouse conditions developed powdery mildew. All the plants maintained outside developed disease symptoms. During this study, winter temperatures were fairly mild and minimum temperatures reached slightly below the freezing point.

\section{DISCUSSION}

These results clearly show that cleistothecia of $M$. pulchra are the primary inocula source for powdery mildew of dogwood in mid-Tennessee. Only six cleistothecia of $P$. guttata were observed in 3 years; therefore, $P$ guttata may not have significant occurrence in mid-Tennessee. However, $P$. guttata and $M$. pulchra were both observed in similar numbers in Kentucky (6), thus indicating a need for more studies to assess the relative importance of these two pathogens in powdery mildew infections over varying environmental conditions in different years and areas. Low production of $P$. guttata cleistothecia in Tennessee is perhaps due to the absence, or low incidence, of one of the mating types needed for cleistothecia development.

Environment has been implicated as one of the several important factors that trigger cleistothecia formation (1). Environments that favor high disease severity increase the probability that mycelia of the compatible mating types would meet and merge to form cleistothecia (13). The occurrence of $M$. pulchra cleistothecia late in the season may reflect an increased period of opportunity for the meeting of two mating types, but it may also reflect changes in host physiology as leaves approach senescence. There was a 1-month difference in cleistothecial development in 1996 compared to 1997 and 1998; this difference is significant because cleistothecia maturation for winter survival requires several weeks (17). Disease severity was high in both 1996 and 1997, but cleistothecia abundance was much lower in 1997 than in 1996. Disease severity was moderate in 1998 and ascocarp abundance was low (Table 1); this suggests that disease severity may not be the only factor that influenced cleistothecium abundance. The timing of cleistothecium formation may be attributable to differences in the environment and its effect on either the pathogen or the physiology of the host.

The moderately resistant cultivar Cherokee Brave and resistant $C$. kousa had low 
disease severity and abundant cleistothecia in 1996 but not in 1997 or 1998 . Similarly, plants that had routine fungicide applications and overall low disease severity sometimes had an abundance of cleistothecia. These observations indicate that, if sexuality and environmental factors favor cleistothecium formation, low disease severity can perpetuate the disease. Preliminary results from another study indicate that cool temperatures may trigger ascocarp formation (M. T. Mmbaga, unpublished), and these temperatures may occur only late in the season, after fungicide applications have been terminated. Under- standing factors that influence cleistothecium formation and development is essential to improve the timing of fungicide applications and reduce the abundance of cleistothecia carried on leaf debris from one season to the next.

Cleistothecia that overwintered on leaf debris continued to open and release ascospores through June (Figs. 1 and 2). Microbial colonization and moisture are usually thought to facilitate degradation of ascocarps on leaf debris. However, in this study, ascospore viability on leaf debris placed on the ground, unprotected from microbial colonization, was as high as that on leaves protected in ziplock bags or in a hanging position not touching the ground. More than $50 \%$ of cleistothecia that overwintered on leaf debris remained viable in May and reproduced infection on diseasefree plants (Table 2); therefore, it is clear that the M. pulchra cleistothecia are functional in Tennessee and constitute an important source of primary inoculum.

The assumption that $M$. pulchra overwinters as mycelium on infected plants was not proven. A single application of the systemic fungicide was expected to eliminate potential mycelium inoculum on the dormant plants, but nontreated plants
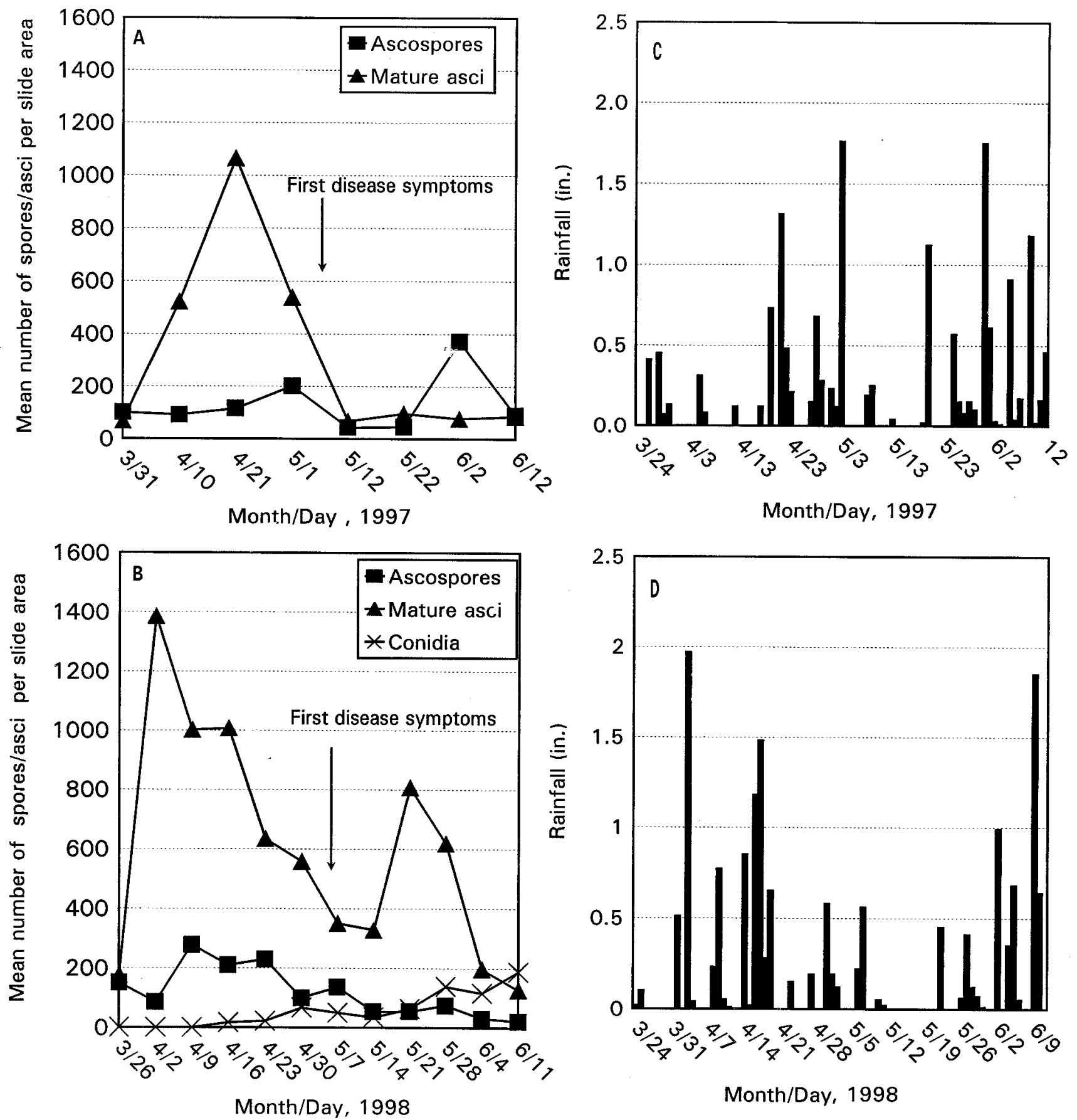

Fig. 3. Mean number of ascospores, asci, and conidiospores trapped from the air around dogwood foliage (A) in 1997 and (B) in 1998 , and rainfall at McMinnville, TN in spring (C) 1997 and (D) 1998. Conidiospores were not counted in 1997. 


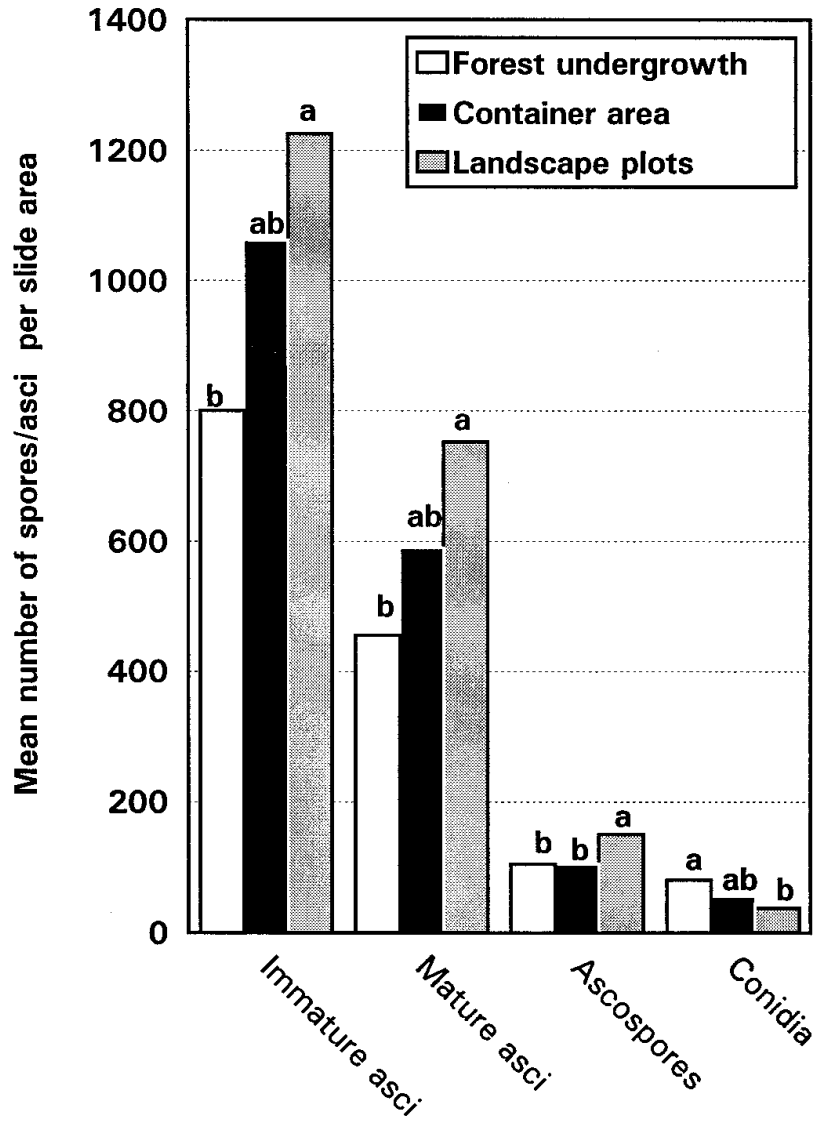

Fig. 4. Airborne spores trapped on sticky slides in spring over 1-week periods at three locations where dogwood was grown at the Nursery Crop Research Station in McMinnville, TN in 1998. Mature asci contained ascospores, immature asci had no ascospores. Letters within clusters indicate significant statistical differences according to a least significant difference test $(P=0.05)$.

should have developed disease symptoms. If mycelial inoculum was a factor, the nontreated plants placed outdoors may have developed disease symptoms earlier than the fungicide-treated plants, but all plants placed outdoors showed disease symptoms at the same time in May. Thus, it was concluded that $M$. pulchra usually cannot survive winter as mycelium in Tennessee because it did not survive during relatively mild winters. Alternatively, it is possible that the frequent freezing and thawing during the cold nights and mild days in winter during 1996 to 1998 may have been detrimental to mycelial survival on the dormant buds.

Based on the timing of disease symptoms on the plants maintained outdoors, and on ascospores trapped from the air, it was assumed that the inoculum source was airborne rather than from mycelia in the previously infected plants. Conidiospores were trapped from the air starting in April, before disease symptoms were visible (Fig. 3 ), suggesting that infection and establishment occurred soon after bud break. Airborne conidiospores suggest availability of secondary inoculum for disease spread but, because conidiospores are delicate and easily disrupted by free moisture (13), the availability of viable ascospores through May and early June may be very important in augmenting disease establishment. The timing of frequent rainfall from April to June tended to coincide with peaks of ascospores and asci trapped from the air (Fig. 3 ), and concurs with previous reports on the role of free moisture on the release of ascospores (13).

These studies demonstrate that cleistothecia on leaf debris remain functional under Tennessee's weather conditions and constitute the predominant mechanism for winter survival and the primary inoculum source for dogwood powdery mildew. Even though cleistothecia were not observed on the stems, leaf debris on transplants or in containers may carry ascocarps that serve as primary inoculum. Measures that eliminate or reduce cleistothecium density or reduce the overwintered leaf debris should reduce primary inoculum and thus reduce initial infection. Primary inoculum is available at bud break; therefore, disease management practices that use early intervention will likely be more successful than other measures.

\section{ACKNOWLEDGMENTS}

I thank the Tennessee nurserymen for the use of their nurseries for this study, $\mathrm{H}$. Sheng for her dedicated assistance throughout this study, and $\mathrm{N}$. Klopfenstein and N. Gawel for their review comments on the manuscript drafts.

\section{LITERATURE CITED}

1. Bullit, J., and Lafon, R. 1978. Powdery mildew of the vine. Pages 525-548 in: The Powdery Mildews. D. M. Spencer, ed. Academic Press, New York.

2. Gadoury, D. M., and Pearson, R. C. 1988. Initiation, development, dispersal and survival of cleistothecia of Uncinula necator in New York vineyards. Phytopathology 78:1413-1421.

3. Gadoury D. M., Pearson, R. C., Riegel, D. G., Seem, R. C., Becker, C. M., and Pscheidt, J. W. 1994. Reduction of powdery mildew and other diseases by over-the-trellis application of lime sulfur to dormant grapevines. Plant Dis. 78:83-87.

4. Hagan, A., and Mullen, J. 1995. Controlling powdery mildew on ornamentals. Ala. Coop. Auburn Ext. Serv. Univ. Ala. Circ. ANR 407.

5. Hagan, A. K., Keever, G. G., and Williams, J. D. 1995. Reaction of dogwood selections to powdery mildew. Ornamental Res. Rep. Ser. No. 10. Ala. Exp. Stn. Univ.

6. Hartman, J. 1998. Evaluation of fungicide application timing for dogwood powdery mildew. Pages 24-25 in: Proc. Dogwood Workshop. Crossnore, NC

7. Leigh, A. K., Windham, M. T., and. Trigiano, R. N. 1998. Natural occurrence of Microsphaera pulchra and Phyllactinia guttata on two Cornus species. Plant Dis. 82:383385.

8. McRitchie, J. J. 1994. Powdery mildew of flowering dogwood. Fla. Dep. Agric. Consumer Serv. Plant Pathol. Circ. No. 368.

9. Mmbaga, M. T. 1997. Over-winter survival of powdery mildew pathogen of dogwood (Cornus spp.). Proc. South. Nurserymen's Assoc. Res. Conf. 42:505-511.

10. Mmbaga, M. T. 1998. Winter survival and source of primary inoculum for powdery mildew of dogwood. Proc. South. Nurserymen's Assoc. Res. Conf. 43:253-261.

11. Ostry, M. E., and Nicholls, T. H. 1982. A technique for trapping fungal spores. North Central For. Exp. Stn. Res. Note NC-283.

12. Ranney, T. G., Grand, L. F., and Knighten, J. L. 1994. Resistance of Cornus kousa taxa to dogwood anthracnose and powdery mildew. Proc. South. Nurserymen's Assoc. Res. Conf. 39:212-213

13. Schnathorst, W. C. 1965. Environmental relationships in the powdery mildews. Annu. Rev. Phytopathol. 3:343-366.

14. Sinclair, W. A., Lyon, H., and. Johnson, W. T. 1987. Diseases of trees and shrubs. Cornell University Press, Ithaca, NY.

15. Weinhold, A. R. 1961. The orchard development of peach powdery mildew. Phytopathology $51: 478-481$.

16. Windham, A. S. 1994. Disease management of woody ornamentals in nurseries and commercial landscapes. Univ. Tenn. Agric. Ext. Serv. PB 1234.

17. Yarwood, C. E. 1957. Powdery mildews. Bot. Rev. 23:235-301. 